\title{
Public Administration and Public Deliberation: An Interpretive Essay
}

\author{
Robert B. Reich $†$
}

How should public administrators decide what to do? Elected officials often will not or cannot tell them. Statutes tend to be written in vague language, unhelpful for "hard cases" of the sort that the legislative drafters never contemplated or did not wish to decide. But it will simply not do to allow public administrators unbridled discretion. Unelected officials are, after all, unelected. Why should citizens trust their judgments?

The first part of this essay is about how our society has come to answer these questions, how it views the place of public administration within a democracy. The second part contains a critique of this dominant view, which through its emphasis on administrative process has led us to focus on how the administrator operates, and overlook the social import of what he does. The final part of the essay suggests an alternative approach to public administration, an approach designed to nurture public deliberation and the discovery of shared public values.

\section{The Recerved View of Public Administration}

The problem of administrative accountability has long been with us, ${ }^{1}$ but it has loomed especially large in postwar America. This is not only because the "administrative state" has grown significantly bigger. ${ }^{2}$ We have also grown more suspicious of bureaucratic discretion. ${ }^{3}$ Section $\mathrm{A}$ describes the historical roots of this suspicion. Section B describes the two dominant visions of public administration-interest group intermediation

$\dagger$ Robert B. Reich teaches business, law, and public management at the John F. Kennedy School of Government, Harvard University.

I wish to thank Frank Michelman, Phil Heymann, Richard Stewart, Mark Moore, Albert Carnesale, Bill Hogan, and Ray Vernon for their helpful comments. This article is part of a larger research project on political management, supported bya grant from the Alfred P. Sloan Foundation.

1. Indeed, government by unelected bureaucrats has long been considered "probably the most important of our negative symbols [of government]." T. ARNOLD, SYMBOLS OF GOVERNMENT 209 (1935). See J. Mashaw, Bureaucratic Justice 11-14, 222-27 (1983).

2. See, e.g., R. Litan \& W. Nordhaus, Reforming Federal Regulation 44 (1983) ("In all, over forty major pieces of legislation dealing with social regulation were passed during [the] sixteenyear period [between 1962 and 1978]." (footnote omitted)); Fiss, The Bureaucratization of the Judiciary, 92 YALE L.J. 1442, 1443 (1983) ("The legislative and executive branches derive their legitimacy from their responsiveness to popular will, and bureaucratization acts as a screen that impairs the responsiveness of officials within these branches.").

3. See K. Davis, Discretionary Justice 3-4, 12, 15-21 (1969). 
and net benefit maximization-that this suspicion has generated, and it highlights the unfortunate consequences of those visions: They deny the possibility that an overarching public interest exists or can exist, or that citizens may change their preferences through deliberating over what is at stake. Section C discusses the incoherence that has resulted from the tension between these two dominant visions.

\section{A. Historical Roots: Pluralism and Accountability}

In the half-century prior to the end of World War II, most Americans viewed public administrators as experts who used their experience and training to discover the best means for attaining goals established by statute. ${ }^{4}$ The administrator's task was merely to solve the problems identified by democratic processes; the legitimacy of his role was no major issue. ${ }^{5}$

In the postwar decades, however, the intellectual foundations on which this faith in administrative expertise rested came under attack. With the substantial attainment of peace and prosperity, there was less consensus about the next set of public goals to be achieved, and little certainty that the application of systematic knowledge would yield a single best means of achieving them. ${ }^{6}$ At the same time, the fresh experience of Fascism, Soviet totalitarianism, and then McCarthyism at home caused many Americans to view with suspicion those who claimed the right to govern in accordance with what they perceived to be the public interest. ${ }^{7}$ Rejecting ideology and recognizing that national agreement about fundamental ends was now more difficult to achieve, scholars in a host of disciplines turned to description as a substitute, and ultimately as the basis for prescription. They concluded that the virtue of American democracy lay in the distinctive characteristics of the American polity: political pluralism, ethical relativism and the resultant capacity to keep moral judgments private and dispersed. ${ }^{8}$ Broad grants of administrative discretion seemed inconsistent

4. See Stewart, The Reformation of American Administrative Law, 88 HARv. L. REv. 1667, 1671-76 (1975) (describing traditional model of American administrative law). One particularly prominent exponent of this view was Woodrow Wilson, who saw public administration as a "detailed and systematic execution of public law" in which discretion was exercised to carry out policies decided upon by elected officials. See Wilson, The Study of Administration, 2 PoL. Scr. Q. 197, 197-217 (1887).

5. There were some exceptions, of course. See Stewart, supra note 4, at 1678-79 (during New Deal era, broad grants of administrative discretion subject to criticism).

6. See E. Purcell, The Grisis in Democratic Theory 735 (1973).

7. See id. at $238,241-42,253$.

8. See id. at 247,251,253-57. According to this view, legislation represents no more than a series of compromises between competing groups. See, e.g., D. Truman, The Governmental Process 350 (1951). For a criticism of this approach, see T. LowI, THE END of LIBERALISM 287-97 (1969). Given the belief that the needs of all groups would be more or less satisfied by the pluralist political process, see R. DAHL, Who Governs? 1-3 (1961), it was not even thought morally or equitably necessary to establish substantive standards for defining the public interest. 
with this vision of society, because they created the possibility that unelected bureaucrats could impose their own ideas on the public. ${ }^{9}$ Accordingly, the postwar intellectual and political project in policymaking became the reconciliation of the practical necessity of broad administrative discretion with this emerging pluralist norm. ${ }^{10}$ The "solution" was found in the idea of administrative process. Henceforth, public administrators would become managers of neutral processes designed to discover "optimal" public policies. ${ }^{11}$ The hallmark of the administrator became procedural expertise in using a set of techniques applicable to all sorts of public problems rather than substantive expertise in solving particular kinds.

\section{B. Two Dominant Visions}

In the past twenty years, two related but conceptually distinct procedural ideals of how public administrators should decide what to do have come to dominate our thinking. Interest-group intermediation, the dominant vision of the late 1960's and early 1970's, was the direct intellectual descendent of pluralist theory. Net-benefit maximization, the dominant vision of the late 1970's and early 1980's, had a more complicated ancestry, for it claimed descent from decision theory and microeconomics as well as from pluralism. Together, the two approaches embodied the post-war shift from a description of how democratic institutions worked to a powerful set of prescriptions for how public decisionmaking should be organized.

\section{Interest-Group Intermediation}

As the rather self-congratulatory pluralist theories of the 1950's and early 1960's gave way to a deepening critique of the American "administrative state" for its insensitivity to less-organized groups and its corresponding tendency to be "captured" by dominant interests, ${ }^{12}$ earlier conceptions of administrator as interest-group intermediary were refined and the interest-group intermediation model emerged. ${ }^{13}$ The public administrator's central responsibility came to be understood as ensuring that all

9. See K. DAvis, supra note 3, at 24-25.

10. For an excellent treatment of this effort, see Stewart, supra note 4, at 1671-711.

11. See J. Mashaw, supra note 1, at 1-11; Stewart, supra note 4, at 1698-702.

12. See, e.g., R. Fellmuth, The INTerstate Commerce Omission 5, 12 (1970); Peltzman, Toward a More General Theory of Regulation, 19 J.L. \& Econ. 211, 239-40 (1976); Stigler, The Theory of Economic Regulation, 2 BeLL J. Econ. \& MGMr. Scr. 3, 10-13 (1971).

13. Not surprisingly, this view of administrative decisionmaking was first developed by political scientists. See, e.g., E. Herring, Public Administration and the Public Interest 133-138 (1936). Later, it became widely accepted by judges, legislators, and legal scholars. See Stewart, supra note 4, at 1683-85. Stewart's discussion of the interest-group intermediation model, which he calls the interest representation model, is especially insightful, and he develops at length a number of points briefly sketched here. See id. at 1760-1813. 
those who might be affected by agency action were represented in decisionmaking deliberations. ${ }^{14}$ The job of the public administrator, according to this vision, was to accommodate - to the extent possible - the varying demands placed upon government by competing groups. The public administrator was a referee, a skillful practitioner of negotiation and compromise. ${ }^{15} \mathrm{He}$ was to be accessible to all organized interests while making no independent judgment of the merits of their claims. ${ }^{16}$ Since, by this view, the "public interest" was simply an aggregation and reconciliation of these claims, the administrator succeeded to the extent that he was able to placate the competing groups. ${ }^{17}$

This model rapidly won converts among members of the judiciary. As early as 1966, for example, the Court of Appeals for the District of Columbia ruled that, in a radio license renewal proceeding representatives of the listening public have standing to intervene in Federal Communications Commissions proceedings. ${ }^{18}$ The ruling was based on the idea that consideration of such viewpoints was necessary to ensure a decision responsive to public needs; ${ }^{10}$ failure to allow intervention by the public invited capricious decisionmaking. ${ }^{20}$ Other court decisions required that an agency seek out representatives of opposing views, that it affirmatively consider all such views, and that it also consider alternate policy choices in light of their impact on all affected interests. ${ }^{21}$ Courts also required that all relevant information from agency files or consultants' reports be disclosed to all participants for comment, that agency announcements of proposed rulemaking give the agency's view of the issues, and that agency decision-makers generally refrain from communicating in secret with particular claimants. ${ }^{22}$ Thus, interest-group intermediation became more

14. For an analysis of this prevailing view, see Stewart, supra note 4, at 1748-60.

15. See, e.g., T. LowI, supra note 8, at 51; Cutler, The Case for Presidential Intervention in Regulatory Rulemaking by the Executive Branch, 56 TuL. L. REv. 830, 833-37 (1982).

16. See T. LowI, supra note 8 , at 71 .

17. For a critique of this prevailing view, see $i d$. at 55-97.

18. Office of Communication of the United Church of Christ v. FCC, 359 F.2d 994, 1000-06 (D.C. Cir. 1966).

19. Id. at 1001-02.

20. Id. at 1003-04.

21. See, e.g., Scenic Hudson Preservation Conf. v. FPC, 354 F.2d 608, 620-25 (2nd Cir. 1965), cert. denied, 384 U.S. 941 (1966); Friends of the Earth v. Atomic Energy Comm., 485 F.2d 1031 (D.C. Gir. 1973). For an extended discussion of judicial developments, see Stewart, supra note 4. Public participation was further aided by several statutes that provided funding for interest groups' involvement in agency decisions. The Federal Trade Commission Improvement Act of 1975, 15 U.S.C. § 57(a) (1982), for example, authorized the FTC to pay attorneys' fees and costs of rulemaking participation to any group representing an interest that "would not otherwise be represented in such a proceeding" and whose representation "is necessary for a fair determination of the rule-making proceeding." Id. $\$ 57(\mathrm{a})(\mathrm{h})(1)$.

22. On the rise of notice and comment rulemaking, see Scalia, Vermont Yankee: The APA, the D.C. Circuit and the Supreme Court, 1978 SuP. CT. REv. 345. For a summary of these and other related developments, see Diver, Policymaking Paradigms in Administrative Law, 95 HARV. L. REv. 
open to public scrutiny - or rather, the scrutiny of organized groups with both the incentive of concentrated interest and sufficient resources to extract information from the government.

These developments increasingly formalized the rulemaking process, ${ }_{2}^{23}$ and made it more necessary for administrators to reach workable compromises with groups possessing the resources to challenge their decisions on procedural grounds. Such groups could now use litigation as a threat to . delay implementation of administrators' decisions for years. ${ }^{24}$ Absent accommodation, implementation of agency decisions became all but impossible. ${ }^{25}$

\section{Net-Benefit Maximization}

The net-benefit maximization form of policymaking ${ }^{26}$ grew out of the decisionmaking tools that had first been successfully applied in the Second World War for allocating resources and planning strategy, ${ }_{2}^{27}$ and microeconomic theory. ${ }^{28}$ In this vision of public administration, the administrator was primarily an analyst, rather than a referee. His first responsibility was to figure out the theory of market failure underlying a broad enabling statute, and then to apply that theory to the circumstances at hand by determining whether intervention would improve overall efficiency. ${ }^{20}$ His second duty was to structure the decisionmaking process so as to make explicit the public problem at issue, alternative means of remedying it, and the consequences and trade-offs associated with each

393, 401-02, 409-13, 421-28 (1981); Stewart, supra note 4, at 1671-75; Verkuil, Jawboning Administrative Agencies: Ex Parte Contacts by the White House, 80 Colum. L. Rev. 943, 966-78 (1980).

23. See Pederson, Formal Records and Informal Rulemaking, 85 YALE L.J. 38, 40-41 (1975).

24. See Stewart, supra note 4, at 1679 (development of procedural requirements "reduced effective agency power by affording litigating tools to resistant private interests").

25. Sometimes, when ideologies or interests were irreconcilable, agency officials were unable to obtain accommodation. See, e.g., Vermont Yankee Nuclear Power Corp. v. Natural Resources Defense Council, 435 U.S. 519 (1978). In response to the long delays in the area of nuclear power, the Supreme Court eventually limited the power of federal courts to impose procedural requirements on informal rulemaking beyond the procedures laid out by the Administrative Procedure Act. See Scalia, supra note 22 , at $358-59$.

26. Professor Colin Diver's model of "comprehensive rationality" corresponds in important ways with the model of net-benefit maximization set forth here. For Professor Diver's analysis and his critique of his model, see Diver, supra note 22, at 396-99, 409-34.

27. Techniques for effective planning developed during the Second World War or shortly thereafter included cybernetics, see N. WIENER, Cybernetics 19-39 (1948); general system theory, see L. von Bertalanffy, General System Theory: Foundations, Development, Applications 15 (1968); game theory, see J. von Neumann \& O. Morgenstern, Theory of Games and EcoNOMIC BEHAvioR (1944); decision theory, see Wald, Foundations of a General Theory of Sequential Decision Functions, 15 Econometrics 279 (1947); and information theory, see C. SHaNnoN \& W. Weaver, The Mathematical Theory of Communication (1949). See generally Diver, supra note 22, at 398-402 (discussing theories underlying comprehensive rationality model of policymaking).

28. See Diver, supra note 22 , at 398.

29. See S. Breyer, Regulation and Its Reform 24-28 (1982); R. Litan \& W. Nordhaus, supra note 2 , at $36-39$. 
solution. ${ }^{30} \mathrm{He}$ would then choose the policy option yielding the largest net benefit or greatest "social utility." In making these calculations, the administrator often would use market prices (like land values in a pollutionfree area) to suggest citizens' willingness to pay for non-market goods (like clean air). Under this approach, the shift from description to prescription was as complete as in the preceding vision: How people acted in the market to satisfy their desires was taken as a template for how public managers should decide what to do.

Net-benefit maximizing became a cornerstone of regulatory reform efforts. Between 1965 and 1980, Congress enacted approximately forty new laws-on health, education, transportation, housing, the environment, and agriculture-that called for evaluation of the economic impact of regulations proposed under them. ${ }^{31}$ In addition, the Ford, Carter, and Reagan administrations required that agencies subject major regulations to a "regulatory analysis" to ensure that the costs of those regulations were justified by their benefits. ${ }^{32}$ Similar efforts cropped up at the state level. ${ }^{33}$

At the same time, and with increasing boldness, the courts accepted the notion that public administrators should seek to maximize net benefits. ${ }^{34}$ Such judicial action, however, rarely reflected a decision to reject interestgroup intermediation in favor of net-benefit maximization; rather, the courts simply saw their job as ensuring that the agencies made good-faith efforts at doing both. ${ }^{35}$

While such analysis could lend governmental actions an air of quantitative precision, it could not legitimize the distributive consequences that are inherent in governmental action. Policymakers who sought to maximize net benefits tried to solve the question of distributional legitimacy by separating issues of efficiency from those of equity ${ }^{36}$ Once an efficient solution was determined-one that maximized net benefits-then presumably the

30. See S. BREYer, supra note 29, at 5-6; R. LrTAN \& W. NoRdhaus, supra note 2, at 81-99; E. Stokey \& R. Zeckhauser, A Primer for Policy Analysis 5-6 (1978).

31. See M. Weidenbaum, Business, Government, and the Public 7-11 (2d ed. 1981).

32. See Exec. Order No. 12,291, 3 C.F.R. $\$ 127$ (1982) (Reagan program); Exec. Order No. 12,044, 3 G.F.R. $\S 152$ (1979) (Carter program); Exec. Order No. 11,821, 3 C.F.R. $\$ 926$ (1975) (Ford program). See generally Bruff, Presidential Power and Administrative Rulemahing, 88 YALE L.J. 451 (1979) (examining appropriate extent of presidential involvement in rulemaking in light of separation-of-powers doctrine).

33. See, e.g., B. Schwartz, Administrative Law: A Casebook 75-79 (2d ed. 1982).

34. For examples of cases in which courts adopted this approach, see Aqua Slide 'N 'Dive Corp. v. Consumer Prods. Safety Comm., 569 F.2d 831, 837-38 (5th Cir. 1978) (agency used faulty reasoning); Ethyl Corp. v. EPA, 541 F.2d 1, 34-36 (D.C. Gir. 1975), cert. denied, 426 U.S. 941 (1976) (same); Portland Cement Ass'n v. Ruckelshaus, 486 F.2d 375, 392-95 (D.C. Cir. 1973), cert. denied, 417 U.S. 921 (1974) (agency failed to set forth its theories); Pillai v. CAB, 485 F.2d 1018, 1027 (D.C. Cir. 1973) (agency artificially narrowed options); International Harvester Co. v. Ruckelshaus, 478 F.2d 615, 641 (D.C. Cir. 1973) (agency used faulty reasoning).

35. See Diver, supra note 22 , at 428 .

36. See E. Stokey \& R. ZECKHAUSER, supra note 30 , at 134-58. 
proceeds could be redistributed according to need or worth. ${ }^{37}$ But this "solution" only served to bring forward once again the fundamental problem: The model lacked any theoretically defensible method for deciding that the wishes of one individual or group are either stronger or worthier than those of another. ${ }^{38}$

The distributive consequences of government action exposed a second tension within the model. In practice, distributive judgments tended to rest on a pluralist vision, one that perceived individuals as members of groups, the members as possessing certain common characteristics, and the groups as having some specific and identifiable relationship to one another. These perceptions, in turn, could be drawn reliably only from the way in which such groups actually organized and characterized themselves, how they defined their memberships, and what they saw to be their central purposes. Thus, net-benefit maximizers found themselves analyzing group choice-even though the model in theory held that the only preferences of relevance to the policymakers were individual preferences. ${ }^{38}$

\section{Practical Differences}

These two approaches to administrative policymaking-interest-group intermediation and net-benefit maximization-have coexisted uneasily. While they have rested on the same pluralist vision, they have diverged in a variety of ways. The first divergence concerns objectives. Interest-group intermediation has assumed that the objective behind a particular government intervention will emerge only from the interactions of divergent participants. ${ }^{40}$ By contrast, the maximization of net benefits approach has required that the objectives be articulated in advance and as specifically and narrowly as possible. ${ }^{11}$ The second divergence concerns evidence. The interest-group intermediary approach has assumed that the facts at issue are the articulated preferences of parties likely to be affected by a rule. ${ }^{42}$ On the other hand, the net-benefits approach has focused on market decisions, such as a group's demonstrated willingness to pay to obtain an analogous benefit or avoid an analogous harm. ${ }^{43} \mathrm{~A}$ final divergence concerns the criteria for a good decision. The interest-group intermediary approach has viewed the "best" decision as the one to which the greatest

37. See id. at $137,155-58$.

38. Most economists reject the possibility of making meaningful interpersonal comparisons of utility. See, e.g., Harsanyi, Cardinal Welfare, Individualistic Ethics, and Interpersonal Comparisons of Utility, 63 J. POL. ECON. 309, 309 (1955).

39. See E. Stokey \& R. Zeckhauser, supra note 30, at 281-82.

40. See Stewart, supra note 4 , at 1760-89.

41. See Diver, supra note 22 , at 413.

42. See Stewart, supra note 4, at 1757.

43. See E. Stokey \& R. Zeckhauser, supta note 30, at 149. 
number of the various participants ultimately subscribed most enthusiastically. ${ }^{44}$ But the net-benefit approach has viewed the "best" decision as the most efficient one-one from which no one could improve his own position without equally worsening the position of someone else. ${ }^{45}$

\section{The Present Incoherence of Administrative Policymaking}

These two approaches to public policymaking have, in practice, resulted in something of a hybrid. ${ }^{46}$ While the formal language of policymaking increasingly has borrowed from the accepted argumentation and reasoning of net-benefit maximization, the actual process of coming to a decision has rested ever more firmly on interest-group intermediation.

Ironically, the hybridization of the two procedural visions often has thwarted the effectiveness of both. First, combining the form of net-benefit maximization with the process of interest-group intermediation exacerbates a central problem of interest-group intermediation: the underrepresentation of poor and diffused interests. "Views" that are merely assertions of preference for certain outcomes, and not rigorous estimates of costs and benefits, are easily discounted. Wealthy and well-organized groups are better able to offer sophisticated analyses and rebut alternative (and often less sophisticated) analyses supplied by less well-endowed groups. The very complexity of the analyses has tended to discourage the involvement of a wider range of participants, who feel that they have nothing legitimate to add to this form of public debate.

At the same time, the commingling of the two approaches in this way has aggravated a central problem of net-benefit maximizing, which is the interpersonal comparisons of utilities implied when some people gain and others lose from a policy deemed to maximize net social benefits. ${ }^{48}$ By obscuring the actual patterns of group organization and membership, the hybrid analysis makes the distributional effects of a given decision even more difficult to gauge.

The tension between these competing concepts has further undermined the legitimacy of administrative decisionmaking, and subjected it to repeated criticism-for failing to respond adequately to affected interests

44. See Stewart, supra note 4 , at 1779.

45. One frequently employed guide is the "Kaldor-Hicks criterion," which holds that any social activity is superior to the status quo if the gainers could fully compensate the losers and still retain some net gain. See Hicks, The Foundations of Welfare Economics, 49 EcoN. J. 696 (1939); Kaldor, Welfare Propositions of Economics and Interpersonal Comparisons of Utility, 49 EcoN. J. 549 (1939).

46. See Diver, supra note 22 , at 428 .

47. Some of these groups have, however, succeeded in overcoming this problem to some extent. See S. Lazarus, The Genteel Populists 227-28 (1974) (success of consumer groups).

48. See supra note 39 and accompanying text. 
and for failing to yield efficient solutions. ${ }^{49}$ Proposals for reform have cycled back and forth between the two visions as the inadequacies of first one and then the other are exposed. Given this ambivalence, it is not surprising that the policy decisions resulting from these two approaches have often lacked broad and sustained public support.

\section{Social Learning: A Critique of the Received View}

The muddle into which both dominant approaches to policymaking have fallen is due, I believe, to difficulties lying deeper than the problems of reconciling them, or the technical challenges of accommodating diffused interests or comparing the utilities of different groups. These are symptoms of a more profound failure of both of these devices to legitimize administrative decisions, that is, to inspire confidence among citizens that public administrators are accountable, that they are responsive to popular concerns.

Both procedural devices presume that administrative accountability is largely a matter of putting public authority to the service of what people want. What they want is predetermined. People's preferences are assumed to exist apart from any process designed to discover and respond to them, that is, outside any social or political experience in defining the nature of the problem and attempting to resolve it. ${ }^{80}$ Both devices thus share a view of accountability in which relevant communications all flow in one direction-from individuals' preferences to public officials, whose job it is to accommodate or aggregate them.

This view of accountability in public administration is inaccurate. Individual preferences do not arise outside and apart from their social context, but are influenced by both the process and the substance of public policymaking. In addition, as discussed in Part III, the view is normatively suspect. It leaves out one of the most important aspects of governance in a democracy-public deliberation over public issues. It thereby fails to offer a satisfying model for how public administrators should act.

\section{A. Learning From Administrative Process}

Regardless of substantive outcomes, the administrative process can have a profound effect on perceptions and, hence, on individual preferences.

49. See Shapiro, Administrative Discretion: The Next Stage, 92 YALE L.J. 1487, 1498-99 (1983); Diver, The Wrath of Roth (Book Review), 94 YALE L.J. 1529 (1985).

50. Indeed, it has been suggested that certain of these devices are applicable even in the absence of formal democratic institutions. See, e.g., E. STOKEY \& R. ZECKHAUSER, supra note 30, at 4 ("Most of the materials in this book [concerning the techniques of policy analysis] are equally applicable to $a$ socialist, capitalist, or mixed-enterprise society, to a democracy or a dictatorship, indeed wherever hard policy choices must be made."). 
Such social learning can occur whether the administrator adopts the interest-group intermediation vision or the net-benefit maximization ideal.

\section{Interest-Group Intermediation}

Policymaking premised on interest-group intermediation can profoundly shape the way a citizenry understands what is important to its collective life, what problems it must address, and what is at stake in these decisions. Interest-group intermediation also affects the future capacities of the polity to participate in such deliberations.

To get a more concrete sense of the ramifications of such policymaking, imagine a community whose major industry spews pollutants into the air. Imagine also an administrator who is the head of a state or regional environmental protection agency, or of a department of commerce and industry. Suppose that our administrator-as-intermediary has sought out the views of different groups of citizens about the pollution and about the area's economy. He has listened to leaders of established organizations (the local Chamber of Commerce, the local homeowners' association, the polluting companies), and of other, less prominent groups. Each group leader has presented formal testimony; some have filed reports, analyses, and extensive commentary. The local media have duly reported their views. By this point, many in the community may view the issue as only a decision to be "made," rather than as a problem still needing definition and deliberation. Others perhaps view it as yet another contest primarily between homeowners and industrialists.

The administrator's actions have altered public perceptions and preferences in at least three ways. First, by choosing to listen to certain spokesmen, or subtly encouraging certain groups to come forward, the administrator has shaped public perceptions of what is at stake. These spokesmen have identified the key issues and arguments, defined the relative constituencies, and structured how the emerging debate will proceed. Perhaps the public would have gained a very different understanding of the problem had a different set of representatives and groups participated, for example, low-income tenants living in the vicinity of the plants, or those who enjoy fishing and hiking in the nearby wilderness area. Rather than a contest between homeowners and industrialists, the controversy might have been understood as one between the competing principles of economic growth and environmental conservation, or between white-collar workers in hightechnology firms and blue-collar workers in the basic industries, or all of these and more.

Second, the implicit selection of certain groups and leaders to participate has subtly altered the configuration of influence and political authority in the community. These groups, and those who have spoken on their 
behalf, are now seen as having access to power, and this perception feeds on itself. This effect cannot be avoided by making the selection process somehow fairer; it stems from the impact that a formal hearing process has on the very formation of groups. Prior to the event, there were likely to have been many incipient groupings in the community, since there are a variety of ways in which the same citizens might join together to express different constellations of concerns. We can assume that many of these incipient organizations and leaders were relatively weak, that is, disorganized, lacking any clear focus, as yet incapable of generating strong support. Once officially recognized as participants in the decisionmaking process, however, groups and leaders become semi-official channels through which community views are expressed; accordingly, their focus and support are both enhanced. As issues arise in the future, these groups and their leaders will be among the first to be consulted. Incipient groups and leaders that were not selected (or encouraged) to participate, however, have suffered a corresponding decline in influence and status. Citizens have less reason to involve themselves in such groups or support such leaders because they are perceived to lack standing to articulate public views. They will have even less influence next time.

Finally, the act of participation has turned private concerns into appropriate subjects of public debate and-by implication-of public action. Their very expression has legitimized them. For example, the concerns of homeowners who are exposed to pollutants now have a clear place on the public agenda; the pollution has been transformed from a private act causing private loss into a public problem open to public remedy. These concerns must now be considered in the resulting decision, for under interestgroup intermediation, a good decision is one that addresses such articulated concerns; there are no principled limits to, or goals for, public involvement apart from this. Having become legitimate subjects of public debate and action, such concerns are likely to remain on the public agenda, and to be accommodated in future decisions as well.

In all of these ways, the administrator who regards his job primarily as interest-group intermediator is an active participant in the political development of the community. By recognizing certain groups and leaders, and subtly encouraging others to participate, the administrator-asintermediator has effectively shaped public understandings of what is at stake, perceptions of who has power in the community, and assumptions about what are legitimate subjects of public concern. He thereby has altered the political future. To view him merely as a neutral "intermediary" dramatically underrepresents his role. ${ }^{51}$

51. See R. Reich, Reflections on Boundaries: A Reply to Charles Reich, 2 YAlE L. \& PoL'y 


\section{Net-Benefit Maximization}

The second approach to administrative policymaking, net-benefit maximizing, is no less influential. But here it is the administrator's initial selection of objectives to achieve and options to weigh-rather than of groups and leaders to participate-that tends to shape public perceptions about what is at stake, and the choice of proxy for "willingness to pay" that tends to affect how the public values these stakes.

Let us return to our example, but this time with our public administrator as net-benefit maximizer. In order to analyze the problem and measure public preferences for different solutions, he first must simplify it. He asks himself, What is the most efficient way to reduce the costs of pollution without at the same time increasing other costs? He then considers three alternatives: requiring that the polluting factories install expensive pollution-control technology that would virtually eliminate all dangerous pollutants from the air; requiring that they install less effective but more affordable pollution-control technology; or simply requiring that the factories stop production whenever the prevailing winds are blowing in the direction of populated areas. He then estimates the costs and benefits of each alternative. Requiring the expensive technology will force factories to lay off workers or to close altogether. The more affordable technology will preserve most jobs but will create some health risks for low-income people living in the vicinity and will damage local forests and wildlife. Making production dependent on the prevailing winds would create even more health problems and would, over time, substantially damage vegetation and wildlife. He calculates this latter loss by estimating how many people visit the nearby wilderness area in a given time period, how much money they spend to get there, and how much additional money they would have to spend to travel to alternative wilderness areas. Let us assume that after estimating the costs and benefits of each alternative against doing nothing, the administrator decides that the second alternative would generate the greatest net benefits, and therefore orders the factories to install the moderately effective pollution controls. But the administrator is not insensitive to the distributional effects; he proposes that low-income people living in the vicinity of the plants be given cash grants, with which they can buy or rent housing in non-polluted areas if they wish.

The problem with this mode of analysis is not that the administrator's conclusion about the social utility of the affordable technology relative to the other alternatives will be "incorrect," or that his analysis entails a

REv. 204, 205-10 (shaping values inevitable in government). But see C. Reich, Conflicts Ahead on "The Next American Frontier," 2 YAlE L. \& Pol'y Rev. 191, 195-97 (conflict between open resource-allocation and government neutrality). 
somewhat simplified characterization of reality and a host of choices about how and what to simplify. Of more enduring consequence are the effects of such choices upon the social utility function itself. Like the administrator-as-intermediary's implicit choices of whom to encourage to participate, these analytic choices reverberate through the community because they have public authority behind them. They influence the way people in the community come to think about the problem, its possible solutions, and the values at stake in the decision.

Our net-benefit maximizing administrator, like his interest-group intermediating counterpart, fosters social learning in a variety of ways. First, by stating the objective as achieving an efficient level of pollution control, he transforms a technical objective into a characterization of the public enterprise, which shapes the way people come to understand what is important. Several messages are implied: The air is polluted (it is dangerous to breathe); the pollution is coming from the factories (the factories bear important responsibility for it); the pollution should be reduced but not necessarily eliminated; the factories should bear the clean-up costs but should not have to bear "unreasonable" costs. Such implied messages simultaneously delegitimate other characterizations of the issue, for example, that such pollution is not really a "problem" at all, since the factories have been in operation for over sixty years, even before homes were built in the vicinity, and no one has previously complained; or that the underlying problem is the failure of the local economy to attract new, lesspolluting businesses, so that factory workers could easily obtain suitable new jobs.

Second, the identification of the three alternative solutions contains a set of social messages that surely will influence the way people think about, and act upon, similar problems in the future. One such message is that appropriate solutions are to be found in pollution-control technologies rather than in social programs like relocating families away from the vicinity of the pollution or retraining factory workers for new jobs. Another message is that the identification of alternative solutions and the final choice among them is primarily a technical task for which the average person has no particular competence or relevant knowledge. Together these messages may tend to discourage social responses that draw inspiration and energy from a citizenry's sense of shared responsibility for community problems and its feeling of competence in devising solutions.

Finally, the methods used by the net-benefit maximizer to evaluate the alternatives inevitably affect the way the public comes to view and value certain attributes of their lives. The official act of placing a monetary value on the wilderness area, for example, constitutes a public statement that feelings toward such wilderness areas can be expressed in dollars and 
cents. It thereby subtly transforms wilderness areas into consumer goods whose worth depends upon how well they satisfy us, rather than entities with their own inherent value. ${ }^{52}$ Such an assertion may subtly diminish the public's appreciation of the wilderness. The assumption that "willingness to pay" to travel to such a wilderness area is the proper measure of how we value it, moreover, delegitimizes whatever positive feelings people may have simply because the wilderness area exists nearby; it suggests that the only grounds for complaint or despair, should the area disappear, derive from the direct and personal loss of access. Together, such ideas-that wilderness areas should be valued in terms of how well they satisfy people, and then only on the basis of people's direct and personal experience with them-are powerful social norms that may influence how citizens think about their environment in the future. ${ }^{\mathrm{s}}$

\section{B. Learning From an Altered World}

The substantive decisions that emerge from both interest-group intermediation and net-benefit maximization, or some hybrid of the two, also cannot help but affect future preferences. These decisions alter the world, and thus alter people's experiences of it. ${ }^{54}$ Compare the quite divergent experiences of future generations in the community were the industry to continue to pollute unabated with what they might be were many of the factories to close. The two groups would grow to adulthood in quite different environments: The air would smell different, the atmosphere would look different, the neighboring wildernesss area would or would not exist, the environment would be more or less healthy, many people would have different sorts of jobs. The two groups, experiencing very different realities, may well learn to place different values on such aspects of life as recreation, health, and work. Subsequent decisions involving these values therefore would be likely to diverge, with each group following a different path based on its own experiences. ${ }^{\mathrm{B}}$

Even the choice of policy instrument can generate powerful social sig-

52. For an eloquent statement on behalf of the intrinsic value of the environment, see Sierra Club v. Morton, 405 U.S. 727, 743 (1972) (Douglas, J., dissenting) ("The river as plaintiff speaks for the ecological unit of life that is part of it.").

53. See S. Kelman, What Price Incentrves? 47-53 (1981). Using market prices and expressions of willingness to pay also suffers, of course, from another difficulty. Such values are dependent upon the current distribution of wealth and income. If the current distribution is deemed to be unfair, then these prices cannot be interpreted as appropriate expressions of social welfare.

54. See Stewart, supra note 4, at 1704-05. There is a sparse economic literature on the ways in which tastes are shaped by past experience. Two of the leading articles are Rothenberg, Welfare Comparisons and Changes in Tastes, 43 AM. Econ. Rev. 885 (1953), and von Weiz̈̈aker, Noles on Endogenous Change of Tastes, 3 J. Econ. THEORY 345 (1971).

55. See Tribe, Technology Assessment and the Fourth Discontinuity: The Limits of Instrumental Rationality, 46 S. CAL. L. REv. 617 (1973). 
nals that shape future norms. As we have seen, for example, the administrator who wishes to maximize net benefits typically prefers to give cash to the poor rather than allocate to them a commodity like public housing, on the rationale that it is more efficient to let the poor decide how to spend the cash than to give them something that might not exactly meet their needs. But this view ignores quite different public perceptions attached to the two transfers. Public housing has a clear social meaning: The structures are manifestly "public"; they reflect public action to improve the habitability of the entire area. The structures serve continually to remind the community of these public purposes, and function as a predicate for future public action of a similar sort. A simple transfer of cash would be devoid of these social meanings-so devoid of such meanings that it might not have enough political support to occur in the first place. ${ }^{\text {s8 }}$

In sum, both the process and the substance of policy decisions necessarily generate profound social learning about public values, and set the stage for future public choices. They give rise to new understandings and expectations; they shape policy debates in other, related policy areas; they reconfigure social ideals. It is therefore misleading to view the job of the public administrator simply as responding to pre-existing preferences, expressed either through group leaders or market transactions. Regardless even of his subjective intention to act as a neutral medium through which public preferences are expressed in the absence of direct voting, the public administrator will in fact shape public values. His and our failure to acknowledge this important role leads to decisions that may not reflect what the public would have chosen had the public actually deliberated about them.

\section{The Public Administrator and Public Deliberation}

Neither interest-group intermediation nor net-benefit maximization necessarily entails public deliberation about common values and the community's future. Yet public deliberation is a foundation of democracy. ${ }^{57}$ Such deliberation can lead individuals to revise opinions (about both facts and values), alter premises, and discover common interests. Disagreements and inconsistencies encourage individuals to balance and rank their wants.

56. Marc Landy has used the debate over energy conservation to illustrate the normative and educative function of decisionmaking. Gasoline consumption can be reduced either by rationing or by decontrolling prices. Rationing "informs people that they are expected to do with less," urging common sacrifice. Price decontrol tells the citizen "simply to behave as a consumer" and participate in the market. Government thus has the choice of imparting a moral lesson or remaining silent. See Landy, Policy Analysis as a Vocation (Book Review), 33 WorLd Pol. 468,479 (1981).

57. See R. Dahl, Dilemmas of Pluralist Democracy 13 (1982). 
The discovery that solely personal concerns are shared empowers people to act upon them. Thus, public deliberation helps transform individual valuations into social values; it helps forge collective purposes, and, even more important, helps define and refine public morality. Through such deliberations, individuals become citizens.

This part of the Article develops these themes. Section A describes a recent instance in which the Administrator of the Environmental Protection Agency sought to foster public deliberation about policy decisions. Section B describes the various kinds of social discovery that such deliberation might allow. Section $\mathrm{C}$ explains some of the broader implications for the way public administrators view their role in society.

\section{A. The Asarco Case}

Is it realistic to believe that the public administrator can enhance public deliberation and social learning about what a good decision means? Both the possibilities and limits of such a role emerge from a real world example that parallels the hypothetical example employed so far.

Under section 112 of the Glean Air Act Amendments of $1970,{ }^{58}$ the EPA is required to promulgate national emissions standards for hazardous air pollutants, so as to provide an "ample margin of safety" to protect the public health. ${ }^{69}$ But Congress gave the EPA no guidance for deciding how much safety is "ample." Even a small exposure to certain hazardous pollutants can pose substantial health risks.

The issue received national attention in 1983 when the agency was trying to decide what, if anything, should be done about inorganic arsenic, a cancer-causing pollutant produced when arsenic-content ore is smelted into copper. The problem was particularly serious in the area around Tacoma, Washington, where the American Smelting and Refining Company (Asarco) operated a copper smelter. The EPA had concluded that, in the absence of any controls on Asarco's arsenic emissions, approximately four new cases of lung cancer would be contracted each year in the Tacoma area. ${ }^{60}$ Even after installation of the "best available" pollutioncontrol equipment, there would still be one new case of cancer per year. ${ }^{81}$ But there was an important consideration on the other side of the issue as well. If the EPA were to impose any more onerous condition on

58. Pub. L. No. 91-604, 84 Stat. 1676, 91st Cong., 2d Sess. (1970) (codified as amended at scattered sections of 42 U.S.C. (1982)).

59. Pub. L. No. 91-604, § 112(b)(1)(B), 84 Stat. 1685, 91st Cong., 2d Sess. (1970) (codified as amended at 42 U.S.C. $\$ 7412$ (b)(1)(B) (1982)).

60. Going to the People of Tacoma For Guidance on Arsenic Standard, ENvTL. F., Oct. 1983, at 36, 37-38; see also 48 Fed. Reg. 33,112, 33,130 (1983) (technical discussion of risk probabilities).

61. Going to the People of Tacoma for Guidance on Arsenic Standard, supra note 60, at 38. 
Asarco-requiring, for example, that it use ore containing less arsenic or install a new and far more expensive electric smelter-the company could not afford to continue to operate the plant. ${ }^{62}$ Asarco employed 570 workers with an annual payroll of approximately $\$ 23$ million; the company bought an additional $\$ 12$ million worth of goods from local suppliers. ${ }^{63}$ Closure of the plant therefore would pose serious economic problems for the local economy.

William Ruckelshaus, then Administrator of the EPA, decided that the citizens of the Tacoma area ought to wrestle with the problem. Accordingly, Ruckelshaus flew to Tacoma to announce a series of three public workshops to be held during the summer of $1983 .{ }^{64}$ Their purpose was to acquaint residents with the details of the pollution problem, help them prepare for subsequent formal hearings, and enable them to deliberate about what should be done. ${ }^{65}$ Two of the workshops were held in a local public high school in Tacoma; they attracted environmental groups, local citizens organizations, and a large number of smelter workers. The third workshop took place on Vashon Island, a residential area where the winds of Puget Sound carried many of Asarco's emissions; most of the attendees at this workshop were island homeowners. EPA officials began each workshop by explaining how the agency had estimated health risks from the factory and the likely effects of different levels of pollution control. They then divided the audience into three groups, and had agency officials and staff circulate among the groups to facilitate a more informal discussion. ${ }^{86}$

Some questions concerned technical matters like the reliability of the proposed control equipment and the risk figures and epidemiological studies on which the EPA had based its estimates. Other questions revealed the inadequacy of the EPA's explanation of the relative health risk posed by the smelter: One resident asked whether that risk was greater than the risk posed by auto emissions. ${ }^{67}$ The EPA was later criticized for expecting "a relatively unsophisticated public to understand what these risk figures mean when the environmental establishment in this state doesn't even understand them."

62. L.A. Times, Aug. 13, 1983, at 1, col. 1.

63. Chicago Tribune, July 17, 1983, at 5, col. 1.

64. John F. Kennedy School of Government, Managing Environmental Risk: The Case of Asarco 9-11 (1985) (discussion draft by Henry Lee) (on file at Yale Law Journal) [hereinafter cited as The Case of Asarco]. The ensuing description of the public deliberations that Ruckelshaus and the EPA conducted in Tacoma is based primarily on this more detailed account.

65. Dallas Morning News, July 31, 1983, available in NewsBank 50: E12-13 (1983) (microfiche).

66. The Case of Asarco, supra note 64, at 10-11.

67. Id. at 11 .

68. Id. (quoting the comments of one observer). 
Residents were not solely concerned, however, with the factual basis for the agency's claims. Several residents wanted to discuss the effects of the arsenic emissions on their gardens, ${ }^{68}$ their animals, ${ }^{70}$ and on the overall quality of life. "The personal nature of the complaints and questions made a striking counterpoint to the presentations of meterological models and health effects extrapolations," observed Gilbert Omenn, Dean of the School of Public Health at the University of Washington. ${ }^{71}$ Several residents expressed hostility toward the EPA for involving them in this difficult decisionmaking in the first place. "T2 "These issues are very complex and the public is not sophisticated enough to make these decisions. This is not to say that EPA doesn't have an obligation to inform the public, but information is one thing-defaulting its legal mandate is another."73

These numerous workshops, together with the national attention that Ruckelshaus had deliberately drawn to them by traveling to Tacoma to announce them, created considerable and often unfavorable press coverage. In an editorial on July 16, 1983, entitled "Mr. Ruckelshaus a Caesar," the New York Times argued that "Mr. Ruckelshaus has it all upside down ... . What is inexcusable is for him to impose such an impossible choice on Tacomans." ${ }^{\text {"7t }}$ An article in the Los Angeles Times pointed out the difficulties "in taking a community's pulse .... [Should one] poll the community . . . . [or] count the pros and cons at the massive hearing?"'75 Ruckelshaus was not surprised by the controversy. He said, "Listen, I know people don't like these kinds of decisions .... [W] [Wlcome to the world of regulation. People have demanded to be involved and now I have involved them, and they say, 'Don't ask that question.' What's the alternative? Don't involve them? Then you are accused of doing something nefarious." "78

The rest of the story is somewhat anticlimatic. By early 1985, the EPA still had not promulgated regulations governing arsenic emissions. But in the interim declining copper prices had forced closure of the Asarco smelter. ${ }^{77}$

\footnotetext{
69. Id.

70. Id.

71. Id.

72. Id. at 12.

74. N.Y. Times, July 16,1983 , at 22 , col. 1 .

75. L.A. Times, Aug. 13, 1983, at 1, col. 1.

76. Id.

77. Seattle Times, June 30, 1984, at A10, col. 3.
}

73. Id. Another resident asked, "At this point in time is Asarco in violation of any clear requirements? Why is EPA spending taxpayers' money for this process if Asarco is not violating any laws?" Id. 


\section{B. Deliberation and Discovery}

The Asarco example illustrates the potential for public administrators to enhance social learning in several ways. Simply telling citizens that they will play a part in making the decision gives interested groups an incentive to communicate their point of view to the public-at-large, and gives members of the public an incentive to listen and to seek out forums where public discussion will ensue. During the course of deliberation, people may discover both new information and new perspectives about what is at stake in the decision before them. This may lead individuals not only to modify their choice of means for achieving their ends, but perhaps to reconsider those ends. At the Asarco hearings, for example, an industrial hygenist speaking for the workers discussed the health risks and possible deaths that could result were the smelter to close, due to the increased stress caused by massive unemployment. ${ }^{78}$ An advocate for the Sierra Club attacked the whole perception of "an environment versus jobs issue," arguing that the exploration of new technology that could control arsenic emissions and allow the plant to stay open should, at least initially, be the primary focus of discussion. ${ }^{79}$

Attendance at the forums, along with massive media exposure, also personalized the previously faceless people who may have been seen to make up the opposing side. As people in the community witnessed a tearful woman-diagnosed as ultra-sensitive to arsenic-describe how she and her husband had to sell their farm at a severe loss and leave the area ${ }^{80}$ or met copper workers in danger of losing their jobs, energies may have shifted from "winning" to finding a solution most appropriate to the special character of their community. As Ruckelshaus described it, a feeling of citizenship began to infiltrate even the expressions of advocacy:

Even the residents of Vashon Island, who were directly exposed to the pollution and yet had no employment or financial stake in the smelter, began to ask whether there was a means of keeping the smelter going while reducing pollution levels. They saw the workers from the smelter-encountered them in flesh and blood-and began incorporating the workers' perspective into their own solutions. ${ }^{81}$

During the course of such public deliberations, some citizens may discover that others feel as they do. Without such discovery, those otherwise willing to volunteer time and money to alleviate a social problem may feel

78. The Case of Asarco, supra note 64, at 16-17.

79. Id. at 16 .

80. Id. at 17.

81. Interview with William Ruckleshaus, Feb. 27, 1985. 
inhibited from taking actions. Some may feel their charitable impulses are not widely shared and therefore that it would be futile to act upon them. Others who feel deeply about a problem they have not directly experienced may assume that their feelings are somehow illegitimate because they themselves were not directly affected. The discovery that others share the same feelings may embolden these people to admit and express such views, and seek to persuade others of their validity. ${ }^{82}$

Through deliberation, some may uncover latent concerns over the future well-being of their community that conflict with their present pecuniary interests. Public dialogue may convince a company stockholder that pollution control requirements will affect not only the value of his stock, but the health of his neighbors, and the quality of the wilderness they all will pass on to future generations. He may also feel it important to prevent prolonged community divisiveness over the issue.

Public deliberation may indirectly enhance social learning over time, by educating administrators about how better to elicit public debate. In the Asarco case, the EPA staff learned a great deal about how to get technical information across to the public, and about non-technical concerns the public may harbor. "We also got educated," said one agency analyst. "The questions raised at the workshops sent some people back to the drawing board."'Bs Regional officials believed that this direct exposure to Tacoma's deliberations increased the sensitivity of EPA leaders to the problems faced by agency employees operating inside of Washington. ${ }^{84}$ Moreover, regional staff learned that they better understood local desires and fears than did their Washington counterparts. "After a while," one regional agency official observed "we realized we couldn't let [headquarters staff] do the spiel [in the public workshops]. The people from headquarters were just not enough in touch with the local level . . . . [T]hey were too scientific."ss

In sum, public deliberation allows people to discover latent public values that they have in common with others, and in the process to create new public values. Together, citizens begin to define targets of voluntary action, to identify what they value most about the community, and to uncover goals and commitments that transcend their narrower self-interests.

82. There is a substantial body of research tending to show that citizens will vote the public interest, not their pocketbooks, when their preferences for the former are elicited effectively. For example, many political preferences seem to be shaped more by citizens' conceptions of national economic conditions than by economic circumstances of their personal lives. See Kinder \& Kicwiet, Economic Discontent and Political Behavior: The Role of Personal Grievances and Collective Economic Judgments in Congressional Voting, 23 AM. J. PoL. Scr. 495, 519-24 (1979); Kinder \& Kiewiet, Sociotropic Politics: The American Case, 11 BRIT. J. Pol. Scr. 129 (1981).

83. The Case of Asarco, supra note 64, at 12.

84. Id. at 18.

85. Id. 
Not incidentally, along the way they achieve a deeper understanding of one another, and refine their political identity. This is not to suggest that the experience necessarily forges deeper attachments and overcomes conflict; citizens may uncover deeper divisions and conflicts. But such underlying tensions may have to be addressed eventually; left unattended, they can poison community life. Their discovery on this occasion may make it more difficult to resolve the immediate issue, but easier to deal with the problems to come.

Apart from discouraging exploration of such latent public values, administrative decisionmaking based solely on interest-group intermediation or net-benefit maximization raises an even more troubling concern. The implicit messages of these approaches-that there are no public values to be discovered, and that the "public interest" is no more than an accommodation or aggregation of individual interests-can have a corrosive effect on civic life. These messages may preempt what potential exists for the creation or discovery of shared commitments and public values; they may also call into question the inherent legitimacy of the policy decisions that result. For such policies are then supported not by community consensus but only by debatable facts, inference, and tradeoffs. They lack any authentic governmental character beyond accommodation or aggregation. Those people who disagree with the procedures or conclusions on which the policies are based have every reason to disregard them whenever the opportunity arises. Under these circumstances, disobedience is not a social act-reflecting upon one's membership in a community-but merely another sort of expression of preference.

\section{G. The Job of the Public Administrator}

We now return to the question with which we began: "How should public administrators decide what to do?" The answer: by taking social learning seriously. The job of the public administrator is not merely to make decisions on the public's behalf, but to help the public deliberate over the decisions that need to be made. Rather than view debate and controversy as managerial failures that make policymaking and implementation more difficult, the public administrator should see them as natural and desirable aspects of the formation of public values, contributing to society's self-understanding.

This does not imply that an administrator should abandon interestgroup intermediation and net-benefit maximization. Quite the contrary: Nurturing public values will require that the administrator undertake a great deal of structured activity, including hearing testimony and gathering data. But the context will be quite different, as will be the administrator's aims. First, the administrator will seek to expose the public to a 
range of issues and problems lying in his domain-explicitly trying to tease out latent concerns to which common values may attach. To this end he will make speeches, enlist the involvement of the media, commission studies, and instigate legislative-type hearings-all with an eye toward fomenting deliberation about potentially controversial issues and thereby fostering formation of and discussion about public values.

Second, during the course of these deliberations the public administrator will seek to articulate various visions of the future, each vision comprising a set of potential decisions taken over time. He will urge the public to reflect on these decision streams, asking which vision of the future the public finds most or least attractive, and why.

Third, throughout these exercises the public administrator will function less like a "neutral" public manager than a teacher and guide. ${ }^{86} \mathrm{He}$ will raise difficult and painful issues and seek to focus the attention of the public upon them. He will ask the public to define and redefine the central problems at issue, eliciting a mix of perspectives and frames of reference. And he will try to link these problems to others that the public has deliberated upon in the past, suggesting relationships and interdependencies that may reveal recurring symptoms of deeper, unresolved issues.

A critical challenge for the public administrator responsible for federal regulation will be to foster social learning at the national level where standard-making must ultimately take place. Local experiences like the $\mathrm{Ta}$ coma experiment, however, can be integral, if not essential, to national civic discovery. Just as an attorney general carefully chooses test cases to develop or challenge legal interpretations, the adroit public administrator can carefully select concrete local examples to set the stage for a national debate over difficult value-laden policy choices. This, in fact, was Ruckelshaus' explicit intent in devising and publicizing the Tacoma experiment. Ruckelshaus was not averse to promulgating national standards, but he insisted that these standards reflect concrete trade-offs, realistically considered: "My view is that these are the kinds of tough, balancing questions that we're involved in here in this country in trying to regulate all kinds of hazardous substances . . . [T] [Te societal issue is what risks are we willing to take and for what benefits?"8z "For me to sit here in Washington and tell the people of Tacoma what is an acceptable risk would be at best arrogant and at worst inexcusable." 88

Public administrators may be in a better position than legislators to foster a national debate over certain value-laden issues simply because the

86. See generally J. BURNS, LEADERSHIP 4 (1978) (moral leadership requires that "leaders and led have a relationship not only of power but of mutual needs, aspirations, and values").

87. L.A. Times, Aug. 13, 1983, at 20, col. 3.

88. N.Y. Times, July 13,1983 , at A1, col. 3 . 
administrators deal with specific applications of general principles. Legislators, on the other hand, often have an incentive to keep their discussions to a fairly high level of generality; delving into knotty details will likely be seen as an invitation to controversy. Yet it is through concrete examples of difficulties in applying regulation-real-life stories about community struggles over civil rights for the handicapped, sex discrimination in schools, advertising directed at children, and other intersections of regulation and people's lives-that social learning takes place, even at a national level. Ultimately, such public deliberations may encourage legislators to alter general standards, or cause administrators to design rules that better reflect the citizenry's concerns.

None of this will come easily. In fact, there are formidable obstacles to this approach. First, public administrators and the public at large often tend to equate administrative effectiveness with active decisionmaking and successful implementation. After all, these are concrete achievements that can be measured and upon which reputations can be built. The nurturing of social learning about public values, on the other hand, is an elusive undertaking. How does one measure success in this regard? An administrator who tentatively advances several proposals and stirs controversy about them may appear indecisive or indifferent, if not simply ineffectual. Second, and largely for this reason, the administrator who has a vision of the future will be sorely tempted to "sell" it to the public rather than offer it tentatively for consideration, along with alternative visions. Indeed, administrators who have the clearest vision probably will be the most resistant to exposing it to public criticism. Third, the public often will wish to avoid facing difficult issues and examining the values and visions bound up in them. Many members of the public will resent the tensions and ambiguities inherent in such deliberation. They may prefer that administrators take responsibility for making such decisions. ${ }^{89}$

There are also procedural obstacles. It will be difficult to organize public deliberation in a manner that does not inadvertantly replicate the form of interest-group intermediation and the substance of net-benefit maximization. This is because there is often no readily apparent "public" or "community" with whom to deal. It is likely to be far easier for the administrator to cope with a discrete set of groups and leaders, and a disembodied set of numbers, than with a cacophony of voices in a wide variety of forums. Genuine deliberation will, therefore, consume an inordinate amount of his time and resources. The process also will be timeconsuming for the public, and will require extensive involvement of the

89. See generally G. Calabresi \& P. BobbitT, Tragic Choices (1978) (social decisionmaking reflects unwillingness to acknowledge and take responsibility for tragic choices). 
media. Moreover, there is no guarantee that the resulting social learning will yield a clear consensus in the end. Indeed, the process may cycle out of "control," exacerbating divisions within the community and rendering consensus impossible; such deliberations even may force the hand of elected officials, thereby removing the issue from the administrator and putting it squarely on the political agenda.

These obstacles are not insurmountable. But they do suggest a somewhat cautious approach to initiating public deliberation. Deliberation is most appropriate to administrative decisions that are especially bound up with social values, or that are likely to have important effects on future choices. Quite obviously, appellate courts cannot and should not decide when administrators must resort to public deliberation. No hard and fast rule will identify such decisions, nor dictate precisely how such deliberations will proceed. In fact, the responsibility to nurture public deliberation cannot be seen as a legal duty of public administrators, akin to their statutory duties. It is rather a prudential responsibility deriving from their place in our democratic form of government.

\section{ConCLuSION}

The Asarco episode illustrates some of the benefits-and limitations-of public administration through public deliberation. Only difficult choices over public values can give meaning to such ambiguous statutory terms as "ample margin of safety" when jobs, health, and even lives are at stake. Self-interested preferences as expressed through the advocacy groups these people support, or the market transaction they enter, simply fail to reflect the latent public values involved, and the consequences of these choices for future choices. Such values cannot be adequately mapped onto individual utility functions, nor traded off for other benefits, for they are the products of social life. They are not fixed quantities, but ideals in flux. They are reshaped in the course of discovering shared concerns, arguing over goals, and ultimately creating shared values. For this reason, the decisions based on interest-group intermediation or net-benefit maximization may fail accurately to describe what people want for each other and themselves as members of a community.

Looking back on the Tacoma experiment more than a year later, after he had left the EPA, William Ruckelshaus assessed it like this:

Perhaps I underestimated how difficult it would be to get people to take responsibility, to educate themselves and one another about such a difficult issue. Probably not more than a relatively few citizens of Tacoma learned that for issues like this there is no "right" answer. They would have to decide what they wanted for their community. 
Public Administration and Deliberation

They would have to determine their own future. But even if a handful learned this lesson, then you have a basis for others learning it. You have the beginnings of a tradition of public deliberation about hard issues. And you also have all the other people in the country who watched what happened there in Tacoma, and indirectly learned the same lesson from it. ${ }^{.0}$

90. Interview with William Ruckelshaus, Feb. 27, 1985. 
